\title{
Sindrom Burnout pada Peserta Program Pendidikan Dokter Spesialis Anestesiologi dan Terapi Intensif Fakultas Kedokteran Universitas Padjadjaran
}

\author{
Dessy Sutoyo, ${ }^{1}$ Rudi Kurniadi, ${ }^{2}$ Iwan Fuadi ${ }^{2}$ \\ ${ }^{1}$ Instalasi Bedah dan Anestesi Rumah Sakit Penyangga Perbatasan, Malaka, Nusa Tenggara Timur, \\ ${ }^{2}$ Departemen Anestesiologi dan Terapi Intensif \\ Fakultas Kedokteran Universitas Padjadjaran/RSUP Dr. Hasan Sadikin Bandung
}

\begin{abstract}
Abstrak
Sindrom burnout didefinisikan sebagai kelelahan kronik yang mencakup tiga komponen, yaitu kelelahan emosional, depersonalisasi, dan berkurangnya kepuasan terhadap pencapaian pribadi. Peserta Program Pendidikan Dokter Spesialis (PPDS) berisiko tinggi mengalami kelelahan dan sindrom burnout akibat beban kerja yang tinggi yang dihadapi baik dalam hal melakukan pelayanan dalam bidang anestesi dan beban dalam pendidikannya. Penelitian ini bertujuan mengetahui angka kejadian sindrom burnout pada peserta PPDS Anestesiologi dan Terapi Intensif Fakultas Kedokteran Universitas Padjadjaran (FK Unpad). Penelitian ini menggunakan metode deskriptif dan pendekatan kuesioner yang dilakukan pada peserta PPDS Anestesiologi dan Terapi Intensif FK Unpad yang masih aktif dan memberikan pelayanan di Rumah Sakit Umum Pusat (RSUP) Dr. Hasan Sadikin Bandung pada bulan April 2018 sebanyak 89 orang. Dilakukan penilaian menggunakan kuesioner yang mencakup data demografik, pendidikan dan pekerjaan, pencapaian prestasi pribadi, serta maslach burnout inventory yang sudah diterjemahkan. Hasil penelitian didapatkan angka kejadian sindrom burnout pada peserta PPDS Anestesiologi dan Terapi Intensif FK Unpad adalah 44\%. Simpulan penelitian ini adalah angka kejadian sindrom burnout pada peserta PPDS Anestesiologi dan Terapi Intensif FK Unpad cukup tinggi, yaitu 44\%.
\end{abstract}

Kata kunci: Depersonalisasi, kelelahan emosional, maslach burnout inventory, peserta PPDS Anestesiologi dan Terapi Intensif, sindrom burnout

\section{Burnout Syndrome among Anesthesiology Residents in Universitas Padjadjaran}

\begin{abstract}
Burnout syndrome is defined as chronic exhaustion that is characterized by emotional exhaustion, depersonalization, and a sense of low professional accomplishment. The main component of this syndrome is emotional exhaustion. Residents who are being trained in anesthesiology and intensive therapy department have s high risk to exhaustion that will lead to burnout syndrome due to stressful environment and high work load in both medical service and medical education. The purpose of this study was to assess the incidence of burnout syndrome among residents in Anesthesiology and Intensive Therapy Department, Faculty of Medicine, Universitas Padjadjaran. This was a cross-sectional descriptive study on 89 residents that was performed in April 2018. Assessment was performed using a questionnaire on demographic, education, personal achievement, and medical service data as well as the translated Maslach Burnout Inventory to reveal the incidence of burnout syndrome among residents of Anesthesiology and Intensive therapy department, faculty of medicine, Universitas Padjadjaran. From the analysis, it was discovered that $44 \%$ of the residents experienced burned out syndrom. In conclusion, the incident of burn out syndrome among residents of Anesthesiology and Intensive Therapy Department, Faculty of Medicine, Universitas Padjadjaran is high.
\end{abstract}

Key words: Anesthesiology and intensive care residents, burnout syndrome, depersonalization, emotional exhaustion, Maslach burnout inventory

Korespondensi: Dessy Sutoyo, dr., SpAn, Instalasi Bedah dan Anestesi Rumah Sakit Penyangga Perbatasan, Malaka, Jln. Sukabi Hanawa, Desa Kanamasa, Kecamatan Malaka Tengah, Kabupaten Malaka, Betun, Nusa Tenggara Timur, Email dessy_dawai80@yahoo.co.id 


\section{Pendahuluan}

Sindrom burnout pertama kali ditemukan dalam kamus yang ditulis oleh Merriam Webster sebagai kelelahan fisik, emosional, atau motivasi yang disebabkan oleh stres atau frustasi yang berkepanjangan. Kelelahan terjadi karena kebutuhan energi dan kekuatan yang berlebihan di tempat kerja. ${ }^{1-5}$

Definisi yang paling sering digunakan saat ini adalah definisi yang dibuat oleh Maslach dan Jackson yang mendefinisikan sindrom burnout sebagai sindrom yang mencakup tiga dimensi, yaitu kelelahan emosional, depersonalisasi, dan kepuasan terhadap pencapaian pribadi berkurang. Komponen utamanya adalah kelelahan emosional yang identik dengan pengalaman kelelahan dan hilangnya minat dalam bekerja. Depersonalisasi didefinisikan sebagaiupayamembuatjarakantaradirisendiri dan penerima layanan dengan mengabaikan kualitas khusus diri mereka dan mengabaikan untuk menyenangkan orang lain. Dimensi ini dianggap sebagai elemen defensif sindrom ini. Hal ini ditandai dengan sikap negatif dan tidak peduli terhadap pasien. Perasaan kurangnya pencapaian pribadi muncul ketika efisiensi seseorang terganggu oleh sumber daya yang memadai untuk mengatasinya kurang. ${ }^{1,6-11}$

Penyebab peserta PPDS anestesi rentan terhadap sindrom burnout antara lain adalah jam kerja yang lama dan kekurangan jam istirahat, sedangkan mereka harus mampu meningkatkan kemampuan dan pengetahuan mereka sendiri. Dokter dan peserta PPDS anestesi yang mengalami kelelahan tidak akan mampu mempertahankan standar kinerja untuk waktu yang lama. Performa dapat ditingkatkan dengan mengurangi stres fisik, stres psikologis, stres mental, dan stres fisiologis. Dalam berbagai penelitian kelelahan dianggap menjadi penyebab penting terjadi kesalahan dalam tindakan medis. ${ }^{7,8,11-13}$

Kejadian stres dan sindrom burnout pada peserta PPDS anestesi berpengaruh terhadap keamanan pasien dan kesehatan serta keamanan seorang dokter anestesi dalam menjalankan pekerjaannya. Sindrom burnout ini juga dapat menyebabkan masalah seperti alkoholisme, penyalahgunaan zat, masalah pernikahan, gangguan emosi, penurunan empati, dan penarikan psikologis dari pekerjaan. Karena itu, perlu diambil langkahlangkah untuk memperbaiki lingkungan kerja. ${ }^{1,9}$

Literatur yang ada menunjukkan bahwa banyak faktor yang berperan terhadap perkembangan kejadian sindrom burnout seperti faktor lingkungan dan stres selama pendidikan serta jenis kepribadian seseorang. Angka kejadian sindrom burnout pada peserta PPDS berkisar antara 28\% sampai $45 \% .^{12}$

Penelitian yang telah dilakukan di Turki menyatakan bahwa angka kejadian sindrom burnout lebih tinggi pada peserta PPDS yang menjalani tahun pertama pendidikannya. Tingkat kelelahan emosional dan kelelahan dari segi depersonalisasi peserta PPDS pada pendidikan tahun kedua lebih tinggi dibanding dengan pendidikan tahun ketiga dan keempat, namun tidak ada perbedaan signifikan dalam segi pencapaian prestasi pribadi. Tidak ada perbedaan signifikan pada segi kelelahan emosional, depersonalisasi, dan pencapaian prestasi pribadi dalam hubungannya dengan jumlah jaga malam per bulan, jumlah jam tidur harian, dan penghasilan per bulan peserta PPDS. ${ }^{11}$

Penelitian yang dilakukan terhadap peserta PPDS di Perancis pada tahun 2013 diketahui bahwa sindrom burnout lebih sering didapatkan pada tahun pertama pendidikannya. Sebanyak 25\% peserta PPDS memiliki kelelahan tingkat tinggi dalam hubungannya dengan depersonalisasi, 13,5\% mengalami kelelahan emosional tingkat tinggi, dan $48,1 \%$ mengalami kepuasan yang rendah dalam pencapaian prestasi pribadi. Selain itu, dinyatakan bahwa tidak ada hubungan yang signifikan antara jumlah jam kerja per minggu dan kejadian sindrom burnout. ${ }^{13}$

Alat yang paling umum digunakan untuk menilai apakah seseorang berisiko mengalami sindrom burnout adalah kuesioner Maslach Burnout Inventory (MBI). Terdapat tiga komponen yang dieksplorasi dalam MBI, yaitu kelelahan emosi, depersonalisasi, dan prestasi pribadi melalui 22 pertanyaan. ${ }^{8}$ 
Sampai saat ini belum ada data mengenai kejadian sindrom burnout pada dokter dan peserta PPDS anestesi di Indonesia, terutama pada FK Unpad Bandung. Penelitian ini bertujuan mengetahui angka kejadian sindrom burnout pada peserta PPDS anestesi FK Unpad.

\section{Subjek dan Metode}

Penelitian ini menggunakan metode deskriptif dengan pendekatan kuesioner untuk mengetahui angka kejadian sindrom burnout pada peserta PPDS Anestesi FK Unpad.

Penelitian dilakukan setelah mendapatkan persetujuan Komite Etik Penelitian Kesehatan Fakultas Kedokteran Universitas Padjadjaran/ RSHS. Sampel penelitian mencakup 89 peserta PPDS Anestesiologi dan Terapi Intensif FK Unpad yang datanya diambil pada bulan April 2018.

Data yang diambil menggunakan kuesioner terdiri atas dua bagian: bagian pertama mencakup data sosiodemografik, pendidikan, pekerjaan, serta data waktu luang dan kebiasaan pribadi. Bagian kedua adalah kuesioner MBI, alat yang paling umum digunakan untuk menilai risiko mengalami sindrom burnout. Kuesioner ini sudah diterjemahkan, diadaptasi, dan divalidasi terlebih dahulu oleh penerjemah Indonesia yang terdiri atas 22 pertanyaan. Pertanyaan 1 sampai 7 mengidentifikasi kelelahan emosional, pertanyaan 8 sampai 14 berhubungan dengan depersonalisasi, dan pertanyaan 15 sampai 22 berhubungan dengan pencapaian prestasi pribadi.

Nilai dari jawaban pertanyaan diberikan skala dari 0 sampai 6 yang berarti "tidak pernah" sampai "setiap hari". Nilai yang didapat dijumlahkan pada setiap dimensinya, kemudian dianalisis dan dibandingkan dengan nilai skala MBI seperti pada Tabel 1. Sindrom burnout ditegakkan jika didapatkan kelelahan emosional tinggi dan atau depersonalisasi tinggi disertai pencapaian prestasi pribadi yang rendah. Data hasil penelitian dicatat dan diolah menggunakan program statistical product and service solution (SPSS) versi 24.0 for windows.

\section{Hasil}

Total terdapat 91 peserta PPDS Anestesiologi dan Terapi Intensif FK Unpad yang menjadi sampel penelitian ini, namun 2 peserta PPDS dieksklusi karena sedang menjalani cuti akademik dan peneliti sendiri.

Subjek penelitian rerata berusia $32,53 \pm 3,38$ tahun, jenis kelamin laki-laki lebih banyak dibanding dengan perempuan (68\%), status menikah lebih banyak dibandingkan dengan yang lajang atau bercerai (73\%), subjek yang memiliki anak lebih banyak dibandingkan dengan yang tidak memiliki anak (58\%; Tabel 2).

Berdasar atas data pendidikan dan pekerjaan didapatkan bahwa sebagian besar peserta PPDS dengan tingkatan kompetensi tahap 3 (46\%). Sebagian besar peserta PPDS menjalani jaga malam $\leq 5 x$ per bulan $(57 \%)$, memiliki jumlah jam tidur 5-7 jam per hari (62\%), tidak memiliki penghasilan tetap (61\%), dan menggunakan beasiswa sebagai jaminan pendidikannya (60\%; Tabel 2).

Data waktu luang dan kebiasaan pribadi menunjukkan bahwa sebagian besar peserta PPDS memiliki hobi di luar pendidikannya (91\%), cukup banyak yang menjalani olahraga rutin (44\%), dan hanya sedikit yang memiliki kebiasaan merokok (21\%) dan minum alkohol (13\%). Pada penelitian ini tidak didapatkan peserta PPDS yang menggunakan obat

Tabel 1 Nilai Skoring MBI

\begin{tabular}{lccc}
\hline \multicolumn{1}{c}{ Dimensi/Bagian } & Rendah & Sedang & Tinggi \\
\hline Kelelahan emosional & $\leq 17$ & $18-29$ & $\geq 30$ \\
Depersonalisasi & $\leq 5$ & $6-11$ & $\geq 12$ \\
Pencapaian prestasi pribadi & $\leq 33$ & $34-39$ & $\geq 40$ \\
\hline
\end{tabular}


psikotropika (Tabel 2).

Pada penelitian ini didapatkan hanya

\section{Tabel 2 Gambaran Sosiodemografik, Pendidikan-Pekerjaan, Waktu Luang-Kebiasaan Pribadi}

\begin{tabular}{|c|c|}
\hline Variabel & $\mathrm{n}=89$ \\
\hline \multicolumn{2}{|l|}{ Usia (tahun) } \\
\hline Mean \pm Std & $32,53 \pm 3,38$ \\
\hline Median & 32,00 \\
\hline \multicolumn{2}{|l|}{ Jenis kelamin, $\mathrm{f}(\%)$} \\
\hline Laki-laki & $61(68 \%)$ \\
\hline Perempuan & $28(32 \%)$ \\
\hline \multicolumn{2}{|l|}{ Status pernikahan, f (\%) } \\
\hline Lajang & $22(25 \%)$ \\
\hline Menikah & $65(73 \%)$ \\
\hline Bercerai & $2(2 \%)$ \\
\hline Memiliki anak, f (\%) & $52(58 \%)$ \\
\hline \multicolumn{2}{|l|}{ Tahap kompetensi, f (\%) } \\
\hline 1 & $30(34 \%)$ \\
\hline 2 & $18(20 \%)$ \\
\hline 3 & $41(46 \%)$ \\
\hline \multicolumn{2}{|l|}{ Jaga malam x/bulan, f (\%) } \\
\hline$\leq 5$ & $51(57 \%)$ \\
\hline$>5$ & $38(43 \%)$ \\
\hline \multicolumn{2}{|l|}{ Jam tidur malam hari, jam (\%) } \\
\hline$<5$ & $33(37 \%)$ \\
\hline $5-7$ & $55(62 \%)$ \\
\hline$>7$ & $1(1 \%)$ \\
\hline Punya penghasilan tetap & $35(39 \%)$ \\
\hline \multicolumn{2}{|l|}{ Jaminan pendidikan, f (\%) } \\
\hline Beasiswa & $53(60 \%)$ \\
\hline Mandiri & $36(40 \%)$ \\
\hline Hobi di luar pendidikan, f (\%) & $81(91 \%)$ \\
\hline Kegiatan olahraga rutin, f (\%) & $39(44 \%)$ \\
\hline Merokok, f (\%) & $19(21 \%)$ \\
\hline Minum alkohol, f (\%) & $12(13 \%)$ \\
\hline $\begin{array}{l}\text { Penggunaan obat psikotropika, } \\
\text { f (\%) }\end{array}$ & $0(0 \%)$ \\
\hline
\end{tabular}

Keterangan: untuk data kategorik disajikan dengan jumlah/frekuensi dan persentase, sedangkan data numerik disajikan dengan rerata, median, standar deviasi, dan range sedikit peserta PPDS yang mengalami kelelahan emosional tingkat tinggi (8\%), namun cukup banyak yang mengalami kelelahan tingkat tinggi yang berhubungan dengan depersonalisasi (44\%), dan banyak yang mengalami pencapaian prestasi pribadi rendah (46\%; Tabel 3).

Pada penelitian ini diketahui bahwa peserta PPDS yang mengalami sindrom burnout adalah 44\% (Tabel 4). Persentase peserta PPDS yang mengalami sindrom burnout didapatkan lebih besar pada peserta PPDS laki-laki (49\%), peserta PPDS berstatus lajang (54\%), dan peserta PPDS yang tidak atau belum memiliki anak (49\%; Tabel 5).

Persentase peserta PPDS yang mengalami sindrom burnout lebih besar pada mereka yang tidak mempunyai penghasilan tetap (48\%), menggunakan beasiswa sebagai jaminan pendidikannya (49\%), menjalani jaga malam $>5$ kali per bulan $(47 \%)$, dan peserta PPDS dengan jumlah jam tidur $<5$ jam (47\%). Berdasar atas tahap kompetensinya, persentase sindrom burnout lebih banyak dialami oleh peserta PPDS tahap 1 (50\%; Tabel 6).

Persentase peserta PPDS yang mengalami sindrom burnout lebih besar pada mereka yang tidak memiliki hobi di luar pendidikannya dan tidak menjalani olahraga rutin (46\%). Selain itu, didapatkan pula bahwa persentase sindrom burnout lebih besar pada peserta PPDS yang merokok (47\%) dan minum alkohol (58\%; Tabel 7).

\section{Pembahasan}

Sindrom burnout merupakan kelelahan kronik akibat beban kerja yang tinggi. Peserta PPDS yang mengalami sindrom burnout dapat mengalami penurunan performa dan memengaruhi keamanan pasien. Gejala yang dapat timbul adalah mudah marah, tersinggung, merasa lelah sepanjang hari, menarik diri dari lingkungan, kehilangan komitmen terhadap pendidikan dan pekerjaannya, terkadang menyebabkan insomnia dan mudah menyalahkan orang lain atau pasien. Oleh karena itu, penting mengetahui kejadian 
Tabel 3 Gambaran Nilai skala MBI

\begin{tabular}{lccc}
\hline \multicolumn{1}{c}{ Dimensi (Level) } & Rendah & Sedang & Tinggi \\
\hline Kelelahan emosional, f (\%) & $51(57 \%)$ & $31(35 \%)$ & $7(8 \%)$ \\
Depersonalisasi, f (\%) & $26(29 \%)$ & $24(27 \%)$ & $39(44 \%)$ \\
Pencapaian pribadi, f (\%) & $41(46 \%)$ & $12(14 \%)$ & $36(40 \%)$ \\
\hline
\end{tabular}

Keterangan: untuk data kategorik disajikan dengan jumlah/frekuensi dan persentase

Tabel 4 Gambaran Burnout Point pada Seluruh Residen

\begin{tabular}{lc}
\hline \multicolumn{1}{c}{ Burnout point } & $\mathbf{n = 8 9}$ \\
\hline Burnout & $39(44 \%)$ \\
Tidak Burnout & $50(56 \%)$ \\
\hline
\end{tabular}

Keterangan: untuk data kategorik disajikan dengan jumlah/frekuensi dan persentase

sindrom burnout dan korelasinya. Pada penelitian ini didapatkan jumlah peserta PPDS yang menjadi sampel penelitian adalah 91 orang dengan 2 orang dieksklusi. ${ }^{1,11}$

Pengaruh jenis kelamin terhadap sindrom burnout masih diperdebatkan, namun status pernikahan dan kepemilikan anak memiliki hubungan dengan sindrom ini. Kepemilikan anak dianggap memberikan pengaruh positif dalam meningkatkan rasa kemanusiaan dan menjadi faktor protektif terjadinya burnout. Faktor lain yang berhubungan dengan sindrom burnout meliputi tahapan pendidikan dikaitkan dengan harapan terhadap pencapaian pendidikan dan karirnya. Jumlah jam kerja dan waktu istirahat dikaitkan dengan kelelahan dan kemampuan konsentrasi dalam pendidikan dan pelayanan. Aktivitas sosial dan olahraga dikaitkan dengan kemampuan beradaptasi dan hubungan sosial., ${ }^{911,13,14}$

Kelelahan tingkat tinggi yang lebih besar didapatkan pada dimensi depersonalisasi (44\%). Depersonalisasi didefinisikan sebagai kehilangan rasa memiliki identitas diri dan perubahan tingkah laku menjadi tidak baik dan acuh tak acuh terhadap pasien dan orang sekitar. Hal tersebut dapat terjadi karena ketidakmampuan dalam melaksanakan aktivitas dan tugas yang dihadapi, kurangnya istirahat dan ketidakmampuan menghadapi situasi yang penuh tekanan. Hal ini berkaitan erat dengan pendidikan spesialisasi dikarenakan peserta didik diharapkan mampu memenuhi tuntutan akademis, pelayanan dan tuntutan sosial dalam jam pelayanan yang cukup panjang. ${ }^{9,11}$

Kelelahan emosional rendah pada peserta

Tabel 5 Gambaran Data Sosiodemografik

\begin{tabular}{lcc}
\hline \multicolumn{1}{c}{ Variabel } & Burnout & Tidak Burnout \\
\hline Jenis kelamin, $\mathrm{f}(\%)$ & & \\
Laki-laki (n=61) & $30(49 \%)$ & $31(51 \%)$ \\
Perempuan (n=28) & $9(32 \%)$ & $19(68 \%)$ \\
Status pernikahan, f (\%) & & \\
Lajang (n=22) & $12(54 \%)$ & $10(46 \%)$ \\
Menikah (n=65) & $26(40 \%)$ & $39(60 \%)$ \\
Bercerai (n=2) & $1(50 \%)$ & $1(50 \%)$ \\
Memiliki anak, f (\%) & & $31(60 \%)$ \\
Ya (n=52) & $21(40 \%)$ & $19(51 \%)$ \\
Tidak (n=37) & $18(49 \%)$ & \\
\hline
\end{tabular}

Keterangan: untuk data kategorik disajikan dengan jumlah/frekuensi dan persentase 
Tabel 6 Gambaran Data Pendidikan dan Pekerjaan

\begin{tabular}{lcc}
\hline \multicolumn{1}{c}{ Variabel } & Burnout & Tidak Burnout \\
\hline Punya penghasilan tetap, f (\%) & & \\
$\quad$ Ya (n=35) & $13(37 \%)$ & $22(63 \%)$ \\
Tidak (n=54) & $26(48 \%)$ & $28(52 \%)$ \\
Jaminan pendidikan, f (\%) & $26(49 \%)$ & $27(51 \%)$ \\
$\quad$ Beasiswa (n=53) & $13(36 \%)$ & $23(64 \%)$ \\
Mandiri (n=36) & & \\
Jumlah jaga malam x/bulan (\%) & $21(41 \%)$ & $30(59 \%)$ \\
$\leq 5(\mathrm{n}=51)$ & $18(47 \%)$ & $20(53 \%)$ \\
$>5(\mathrm{n}=38)$ & $15(50 \%)$ & $15(50 \%)$ \\
Tahap kompetensi, $\mathrm{f}(\%)$ & $6(33 \%)$ & $12(67 \%)$ \\
$1(\mathrm{n}=30)$ & $18(44 \%)$ & $23(56 \%)$ \\
2 (n=18) & & $17(53 \%)$ \\
$3(\mathrm{n}=41)$ & $15(47 \%)$ & $31(56 \%)$ \\
Jumlah tidur malam hari, jam (\%) & $24(44 \%)$ & $2(100 \%)$ \\
$<5(\mathrm{n}=32)$ & $0(0 \%)$ & \\
$5-7(\mathrm{n}=55)$ & & \\
$>7(\mathrm{n}=2)$ &
\end{tabular}

Keterangan: untuk data kategorik disajikan dengan jumlah/frekuensi dan persentase

PPDS Anestesi FK Unpad dapat dipengaruhi oleh faktor kenyamanan dalam suasana dan hubungan kerja yang cukup baik antarpeserta PPDS dan konsulen walaupun dihadapkan pada lamanya jam kerja dan tuntutan meningkatkan kemampuan dan pengetahuan mereka sendiri. Kelelahan emosional dapat terjadi akibat kecemasan berlebihan yang akhirnya membuat marah dan kecewa pada diri sendiri. Hal-hal yang berperan dalam

Tabel 7 Gambaran Waktu Luang dan Kebiasaan

\begin{tabular}{lcc}
\hline \multicolumn{1}{c}{ Variabel } & Burnout & Tidak Burnout \\
\hline $\begin{array}{l}\text { Hobi diluar pendidikan, f(\%) } \\
\text { Ya (n=81) }\end{array}$ & $35(43 \%)$ & $46(57 \%)$ \\
$\quad$ Tidak (n=8) & $4(50 \%)$ & $4(50 \%)$ \\
Kegiatan olahraga rutin, f (\%) & & \\
$\quad$ Ya (n=39) & $16(41 \%)$ & $23(59 \%)$ \\
$\quad$ Tidak (n=50) & $23(46 \%)$ & $27(54 \%)$ \\
Merokok, f (\%) & & $10(53 \%)$ \\
Ya (n=19) & $9(47 \%)$ & $40(57 \%)$ \\
Tidak (n=70) & $30(43 \%)$ & $5(42 \%)$ \\
Minum alkohol, f (\%) & & $45(58 \%)$ \\
Ya (n=12) & $7(58 \%)$ & \\
Tidak (n=77) & $32(42 \%)$ & \\
\hline
\end{tabular}

Keterangan: untuk data kategorik disajikan dengan jumlah/frekuensi dan persentase 
kelelahan emosional adalah suasana dan lingkungan kerja serta interaksi terhadap sekitar yang kurang baik serta anggapan kekurangan sumber daya dibanding dengan beban kerja yang dihadapi., ${ }^{9,11}$

Pencapaian prestasi rendah pada penelitian ini mungkin disebabkan oleh harapan hasil pendidikan dalam hal teori dan kemampuan/skill yang terlalu tinggi serta stresor yang dihadapi selama masa pendidikannya yang tidak sesuai dengan yang dibayangkan saat awal memasuki pendidikan dokter spesialisasinya. Kelelahan emosional yang tinggi atau depersonalisasi secara tidak langsung akan menurunkan kepuasan terhadap apa yang dikerjakan dan pencapaian prestasi yang rendah. ${ }^{9,11,15}$

Pada penelitian ini diketahui bahwa peserta PPDS yang mengalami sindrom burnout adalah 44\%. Hal ini serupa denganliteraturyang sudah ada sebelumnya yang menyatakan bahwa angka kejadian sindrom burnout pada peserta PPDS berkisar antara 28\% sampai $45 \%$. Ini menunjukkan bahwa angka kejadian sindrom burnout pada peserta PPDS Anestesiologi dan Terapi Intensif FK Unpad cukup tinggi yang mungkin disebabkan oleh ketidakmampuan dalam melaksanakan aktivitas dan tugas yang dihadapi serta istirahat kurang yang menyebabkan depersonalisasi. Hal ini harus dapat diatasi dengan baik agar tidak berlanjut dan berkembang menjadi sindrom burnout.

Kejadian sindrom burnout pada peserta PPDS Anestesiologi dan Terapi Intensif FK Unpad lebih besar pada peserta PPDS lakilaki, berstatus lajang, dan tidak atau belum memiliki anak. Penelitian yang dilakukan di luar negeri menyatakan bahwa pengaruh jenis kelamin terhadap kejadian burnout masih diperdebatkan. Beberapa penelitian menyatakan sindrom burnout lebih banyak ditemukan pada perempuan dikarenakan lebih emosional dan mudah mengalami kelelahan dan depresi, namun penelitian lain menyatakan lebih banyak laki-laki karena lebih mudah stres dalam pekerjaan nyata, lebih tidak sabar, dan lebih mudah sinis sehingga mudah mengalami depersonalisasi. Selain itu, dinyatakan bahwa lebih banyak terjadi pada mereka yang memiliki anak, namun tidak ada perbedaan signifikan dalam hubungannya dengan status pernikahan. Status pernikahan dan kepemilikan anak dikaitkan dengan faktor dukungan keluarga yang berhubungan dengan personality dan budaya yang ada di Indonesia yang dapat menyebabkan seseorang mengalami kelelahan emosional akibat kecemasan berlebih terhadap kehidupan pribadinya dan depersonalisasi jika merasa tertekan terhadap tuntutan berkaitan dengan kehidupan pribadinya. Pada mereka yang sudah menikah dan memiliki anak mendapatkan dukungan yang lebih efektif dari keluarga dan memiliki efek protektif tehadap kejadian sindrom burnout. . $^{1,9,11}$

Persentase kejadian sindrom burnout yang tinggi didapatkan pada mereka yang tidak punya penghasilan tetap (48\%) atau yang menggunakan beasiswa sebagai jaminan pendidikannya (49\%). Hal ini sedikit berbeda dengan hasil penelitian yang dilakukan di Turki yang menyatakan tidak ada perbedaan signifikan penghasilan dengan terjadi sindrom burnout. Kejadian sindrom burnout ditemukan lebih banyak pada mereka yang mendapatkan beasiswa untuk biaya pendidikannya, mungkin disebabkan oleh biasanya yang mengambil beasiswa adalah peserta didik yang tidak mampu untuk mandiri secara finansial membiayai pendidikan, sedangkan jumlah beasiswa yang diterima mungkin hanya cukup menjamin pendidikan, namun kurang untuk biaya hidup dan lainnya. Selain itu, juga dapat disebabkan oleh sering keterlambatan beasiswa yang diterima peserta PPDS.

Kelelahan akibat beban kerja dan jam kerja yang panjang menyebabkan kurang istirahat dan tidak mampu melaksanakan aktivitas dan tugas yang dihadapi dengan baik yang dapat menyebabkan depersonalisasi serta pencapaian prestasi rendah. Namun, mengurangi jam kerja ternyata tidak selalu menghasilkan kepuasaan kerja yang lebih baik. Hal ini juga menjadi penyebab tersering terjadi kesalahan medis dan penurunan kualitas pelayanan terhadap pasien. Persentase kejadian sindrom burnout yang tinggi pada mereka yang jaga malam $>5$ kali 
per bulan (47\%) dan jumlah tidur malam hari $<5$ jam. Hasil ini hampir serupa dengan hasil penelitian yang telah dilakukan di luar negeri bahwa kelelahan akibat jaga malam dapat menyebabkan penurunan fungsi kognitif dan refleks serta memengaruhi mood dan suasana hati sehingga dapat menyebabkan kelelahan emosional, depersonalisasi, dan berpengaruh juga terhadap kepuasan kerja. Pengaturan waktu yang baik sangat penting peranannya dalam prevensi terjadi burnout. Selain itu, dapat pula dilakukan pembagian tugas dan tanggung jawab antarpeserta PPDS atau refreshing bersama di waktu tertentu. ${ }^{9,14}$

Faktor yang cukup berpengaruh dalam kejadian sindrom burnout adalah tahap studi. Status sebagai peserta PPDS memberikan kontribusi dalam kejadian burnout. Persentase sindrom burnout tertinggi dialami oleh peserta PPDS tahap 1 (50\%). Tingginya persentase kejadian sindrom burnout pada tahap 1 dapat disebabkan oleh beban kerja secara fisik yang lebih berat dibanding dengan tahap lain disertai kondisi yang dihadapi oleh mereka yang sedang dalam proses adaptasi dengan lingkungan dan sistem pendidikan baru sehingga dapat menyebabkan depersonalisasi dan kepuasan pribadi yang rendah. Cukup tingginya angka kejadian sindrom burnout pada peserta PPDS dengan tahap 3 di Unpad dapat disebabkan oleh kelelahan fisik dan emosional, depersonalisasi, dan pencapaian prestasi pribadi yang kurang. Hal ini berkaitan dengan terbatasnya waktu pendidikan dan tuntutan segera menyelesaikan tugas pendidikan, namun harus tetap menjalani kewajiban pelayanan. Kejadian burnout yang rendah pada peserta PPDS dengan tahap kompetensi 2 mungkin berhubungan dengan kelelahan fisik dan emosional yang lebih rendah. Kelelahan fisik rendah karena perasaan memiliki junior yang dapat diberikan instruksi dalam mengerjakan hal yang seharusnya dapat dikerjakan oleh diri sendiri, sedangkan kelelahan emosional rendah karena memiliki senior yang lebih bertanggung jawab dalam pengelolaan pasien. Hasil ini hampir serupa dengan penelitian yang telah dilakukan di Turki dan Perancis angka kejadian sindrom burnout lebih tinggi pada peserta PPDS yang menjalani tahun pertama pendidikannya. 9,13

Penelitian ini menunjukkan kejadian burnout pada peserta PPDSyang tidak memiliki hobi di luar pendidikannya tinggi. Hasil ini serupa dengan beberapa penelitian yang telah dilakukan di luar negeri. Aktivitas sosial dan olahraga memiliki peran dalam pencegahan kejadian sindrom burnout. Interaksi dengan banyakorangdapatmeningkatkan kemampuan komunikasi yang baik, meningkatkan rasa empati, dan meningkatkan rasa percaya diri. Dukungan sosial terbukti mengurangi kejadian burnout. ${ }^{9,14,16}$

Pada penelitian ini didapatkan persentase burnout yang lebih tinggi pada peserta PPDS yang merokok (47\%) dan minum alkohol (58\%). Perilaku ini mungkin saja merupakan bentuk pelarian dari stres yang dialami. Hal ini dapat menunjukkan bahwa konsumsi alkohol dan penyalahgunaan zat sangat terkait dengan depresi dan sindrom burnout. Mencegah sindrom burnout memiliki dampak penting dalam mengurangi kemungkinan penyalahgunaan zat dan obat di antara peserta PPDS anestesiologi. Hal ini serupa dengan penelitian yang telah dilakukan di Brazil angka kejadian sindrom burnout lebih tinggi pada mereka yang merokok atau minum alkohol. ${ }^{11}$

Semua peserta PPDS Anestesiologi dan Terapi IntensifFKUnpad memiliki pembimbing akademik yang dapat memberikan bimbingan setiap waktu. Sistem pendidikannya pun disusunsecaraterpadu tiap-tiap tahap memiliki kompetensi dan tanggung jawab yang berbeda. Selain itu, suasana pendidikan dan pelayanan dibuat dalam suasana kekeluargaan sehingga peserta PPDS tidak merasa tertekan dan stres. Hal ini dapat menjadi mekanisme pertahanan untuk mengurangi kejadian sindrom burnout pada peserta PPDS Anestesiologi dan Terapi Intensif FK Unpad.

\section{Simpulan}

Angka kejadian sindrom burnout pada peserta PPDS Anestesiologi dan Terapi Intensif FK Unpad cukup tinggi. Faktor yang berperan dalam berkembangnya kejadian sindrom 
burnout pun sudah diketahui. Diperlukan penatalaksanaan yang baik untuk mengurangi dan mencegah kejadian sindrom burnout.

\section{Daftar Pustaka}

1. Thomas NK. Resident burnout. JAMA. 2004; 292(23):2880-9.

2. Vinson AE. Burnout in anesthesiologist: an Update. ASA Article. 2014;78 (11):18-20.

3. Hyman SA, Michaels DR, Berry JM, Schildcrout JS, Mercaldo ND, Weinger MB. Risk of burnout in perioperative clinicians: a survey study and literature review. Anesthesiology. 2011;114(1):194-204.

4. Veintemilla F. The stress caused by medical emergencies. Fatigue and its correlation with diseases, suicide and medical malpractice. Dalam: Neto GFD, penyunting. Occupational well-being in anesthesiologists. Volume 1. Brazil: Rio de Janeiro; 2014. hlm. 37-50.

5. Heinemann LV, Heinemann T. Burnout research: emergence and scientific investigation of a contested diagnosis. SAGE Open. 2017;7(1):1-12.

6. Khetarpal R, Veena C, Jangjit K, Ashish V. Occupational stress in anesthesiologists and coping strategies: a Review. IJSS. 2015;3(6):188-92.

7. Maslach C, Jackson S, Leiter M. The Maslach burnout inventory manual. Dalam: Zalaquett CP, Wood RJ, penyunting. Evaluating stress: a book of resources. Edisi ke-3. USA: The Scarecrow Press; 1997. hlm. 191-218.

8. Gupta NGA, Garg R. Professional burnout in anaesthesia and critical care
- How to decrease it. J Anaesth Crit Care. 2015;2(3):00056.

9. McKinley TF, Boland KA, Mahan JD. Burnout and interventions in pediatric residency: a literature review. Burnout Res. 2017;6:9-17.

10. Magalhaes E, Oliveira ÁCMdS, Goveia CS, Ladeira LCA, Queiroz DM, Vieira CV. Prevalence of burnout syndrome among anesthesiologists in the federal district. Rev Bras Anestesiol. 2015;65:104-10.

11. Turgut N, Karacalar S, Polat C, Kiran O, Gultop F, Kalyon ST, dkk. Burnout syndrome during residency. Turk J Anaesthesiol Reanim. 2016; 44(5):258-64.

12. Ishak WW, Lederer $S$, Mandili C, Nikravesh $\mathrm{R}$, Seligman L, Vasa M, dkk. Burnout during residency training: a literature review. JGME. 2009;1(2):236-42.

13. Chaput B, Bertheuil N, Jacques J, Smilevitch D, Bekara F, Soler P, dkk. Professional burnout among plastic surgery residents. Ann Plast Surg. 2015;75(1):2-8.

14. Shidhaye RV, Divekar DS, Dhulkhed VK, Goel G, Gupta A, Shidhaye R. Evaluation of stressors and coping strategies for Stress in Indian anaesthesiologists. Indian J Anaesth. 2011;55(2):193-8.

15. Carlotto MPA, Bones K, Oliveira-Machado R. Prevalence and factors associated with burnout syndrome in professionals in basic health units. Cienc Trab. 2013;15(47):7680

16. Pereira-Lima K, Loureiro SR. Burnout, anxiety, depression, and social skills in medical residents. Psychol Health Med. 2015;20(3):353-62. 